\title{
Adsorption of chia proteins at interfaces: Kinetics of foam and emulsion formation and destabilization
}

\author{
Débora N. López ${ }^{\text {a, b, *, Valeria Boeris }}{ }^{\text {a, b }}$, Darío Spelzini ${ }^{\text {a, b }}$, Carla Bonifacino ${ }^{\mathrm{c}}$, Luis A. Panizzolo ${ }^{\mathrm{c}}$, \\ Cecilia Abirached ${ }^{c}$ \\ a Área Fisicoquímica, Departamento de Química Física, Facultad de Ciencias Bioquímicas y Farmacéuticas, Universidad Nacional de Rosario- CONICET, Suipacha 531, Rosario, Argentina \\ ${ }^{\mathrm{b}}$ Facultad de Química e Ingeniería del Rosario, Pontificia Universidad Católica Argentina, Pellegrini 3314, Rosario, Argentina \\ ${ }^{c}$ Departamento de Ciencia y Tecnología de los Alimentos, Facultad de Química, Universidad de la República, Av. General Flores 2124, Montevideo, Uruguay
}

\section{ART ICLE INFO}

Keywords:

Chia protein isolates

Interfacial properties

\begin{abstract}
A B S T R A C T
Chia proteins were extracted by solubilisation at $\mathrm{pH} 10$ or 12 and precipitated at $\mathrm{pH} 4.5$. Isolates were named as CPI10 and CPI12, according to their extraction $\mathrm{pH}, 10$ or 12, respectively. The surface properties of both isolates were studied at neutral conditions. Foams were formed by air bubbling and both the formation and destabilization processes were analysed by conductimetry. The extraction $\mathrm{pH}$ significantly affected the interfacial properties of chia proteins. The higher surface hydrophobicity in CPI10 led to more flexible proteins with improved foaming properties. Foams formed by CPI10 were more stable than those by CPI12 due to the formation of a thicker interfacial film, which meant a greater ability to retard liquid drainage. Freshly-made coarse emulsions stabilized with CPI12 showed a lower mean droplet size and a significantly lower degree of overall destabilization than those stabilized with CPI10. None of the two emulsions showed flocculating effect.
\end{abstract}

\section{Introduction}

The partial displacement of animal proteins is undoubtedly conducted by vegetable proteins, which have emerged as a promising source of high-quality proteins [1]. The increasing demand for plant proteins is based on their low production cost, high availability in nature and the enhanced consumers' preference for healthy ingredients. Protein isolates or concentrates are therefore used to replace meat or milk proteins in many processed foods [2]. In this context, chia proteins have regained central importance in recent years due to their potential from both health and nutritional standpoints [3].

Proteins play an essential role as surfactants in food dispersed systems, e.g. foams and emulsions. Their surface activity depends mainly on the physical, chemical and conformational characteristics of proteins, which are affected by extrinsic factors such as temperature, ionic strength and $\mathrm{pH}$ [4]. Thus, the way by which proteins are extracted from seeds becomes essential to determine their structural properties and the consequent functional properties of the obtained isolates.
The effect of the extraction conditions on the structural properties of chia protein isolates (CPI) has recently been demonstrated [5]. These isolates showed desirable functional properties for use in the food industry [6]. Other studies have reported the ability of chia proteins to form foams and emulsions $[2,7,8]$, although the underlying mechanisms of such foaming and emulsifying properties have not yet been studied.

The aim of this work was to analyze the effect of the extraction conditions ( $\mathrm{pH} 10$ or 12$)$ of chia proteins on their ability to form and stabilize foams and emulsions at neutral $\mathrm{pH}$. CPI behavior at the air/water interface has been characterized in order to evaluate the suitability of these isolates in the development of food products.

\section{Materials and methods}

\subsection{Materials}

Milled and partially defatted chia seeds were purchased at a local market (Sturla S.R.L, Buenos Aires, Argentina).

\footnotetext{
* Corresponding author at: Facultad de Ciencias Bioquímicas y Farmacéuticas, Universidad Nacional de Rosario - CONICET, Suipacha 531, Argentina.

Email address: dlopez@fbioyf.unr.edu.ar (D.N. López)
} 


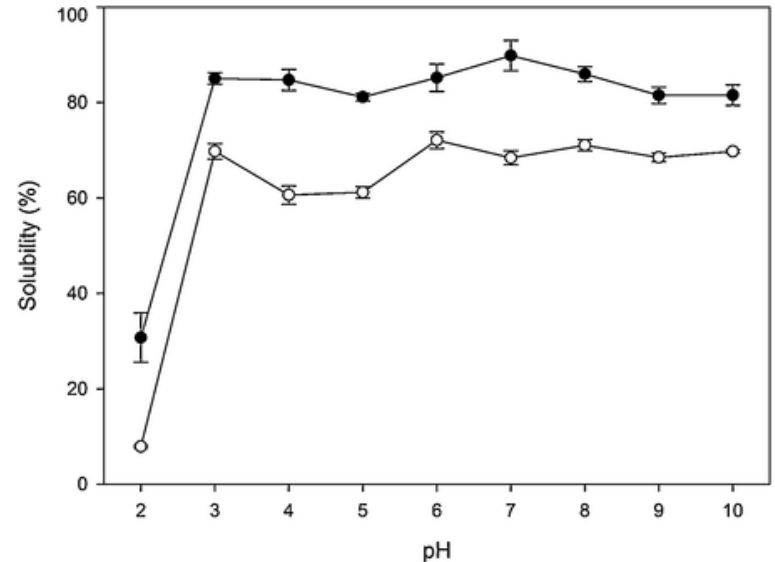

Fig. 1. Solubility profiles of chia proteins extracted at $\mathrm{pH} 10$ (black circles) or 12 (white circles).

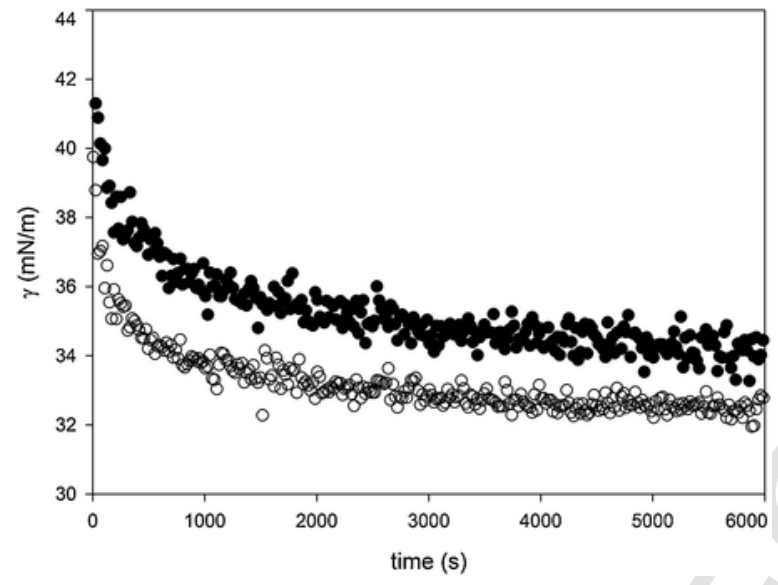

Fig. 2. Reduction of surface tension over time for air/water interfaces stabilized with chia proteins extracted at $\mathrm{pH} 10$ (black circles) or 12 (white circles).

Table 1

Parameters of the study of foaming and emulsifying properties of chia proteins.

\begin{tabular}{lll}
\hline & CPI10 & CPI12 \\
\hline & Foaming properties & \\
$\mathrm{k}_{\mathrm{a}}\left(\mathrm{s}^{-1}\right)^{*}$ & $0.12 \pm 0.01^{\mathrm{a}}$ & $0.08 \pm 0.01^{\mathrm{a}}$ \\
$\mathrm{V}_{\mathrm{a}}(\mathrm{mN} / \mathrm{m})^{*}$ & $5.8 \pm 0.9^{\mathrm{a}}$ & $3.48 \pm 0.03^{\mathrm{a}}$ \\
$\mathrm{k}_{\mathrm{r}}\left(10^{-4} \mathrm{~s}^{-1}\right)^{* * *}$ & $94 \pm 3^{\mathrm{a}}$ & $50 \pm 3^{\mathrm{b}}$ \\
$\mathrm{V}_{\mathrm{r}}(\mathrm{mN} / \mathrm{m})^{* * *}$ & $5.6 \pm 0.6^{\mathrm{a}}$ & $1.5 \pm 0.1^{\mathrm{b}}$ \\
$\mathrm{V}_{\mathrm{e}}(\mathrm{mN} / \mathrm{m})^{* *}$ & $37.2 \pm 0.1^{\mathrm{a}}$ & $32 \pm 2^{\mathrm{a}}$ \\
$\mathrm{E}(\mathrm{mN} / \mathrm{m})^{* * * *}$ & $30 \pm 1^{\mathrm{a}}$ & $20 \pm 2^{\mathrm{b}}$ \\
$\mathrm{E}_{\mathrm{v}}(\mathrm{mN} / \mathrm{m})^{* * * *}$ & $5.1 \pm 0.5^{\mathrm{a}}$ & $9 \pm 2^{\mathrm{b}}$ \\
$\mathrm{E}_{\mathrm{d}}\left(\mathrm{mN} / \mathrm{m}^{* * * *}\right.$ & $29 \pm 1^{\mathrm{a}}$ & $18 \pm 2^{\mathrm{b}}$ \\
$\mathrm{V}_{0}(\mathrm{~mL} / \mathrm{s})^{* * *}$ & $0.265 \pm 0.003^{\mathrm{a}}$ & $0.22 \pm 0.01^{\mathrm{b}}$ \\
$\mathrm{k}_{\mathrm{g}}\left(10^{-4} \mathrm{~mL}^{-1} \mathrm{~s}^{-1}\right)^{*}$ & $35 \pm 2^{\mathrm{a}}$ & $36 \pm 3^{\mathrm{a}}$ \\
$\mathrm{k}_{\mathrm{d}}\left(10^{-6} \mathrm{~mL}^{-1} \mathrm{~s}^{-1}\right)^{* * * *}$ & $8 \pm 4^{\mathrm{a}}$ & $540 \pm 30^{\mathrm{b}}$ \\
$\mathrm{V}_{\mathrm{g}}(\%)^{* *}$ & $89.9 \pm 0.1^{\mathrm{a}}$ & $76 \pm 2^{\mathrm{b}}$ \\
$\mathrm{V}_{\mathrm{d}}(\%)^{* * *}$ & $10.1 \pm 0.1^{\mathrm{a}}$ & $21 \pm 1^{\mathrm{b}}$ \\
$\mathrm{k}_{\mathrm{h}}\left(10^{-5} \mathrm{~s}^{-1}\right)^{* * * *}$ & Emulsifying properties & \\
$\mathrm{k}_{\mathrm{s}}\left(\mathrm{s}^{-1}\right)^{*}$ & $137 \pm 0.5^{\mathrm{a}}$ & $70 \pm 2^{\mathrm{b}}$ \\
$\mathrm{BS}_{\mathrm{h}} / \mathrm{BS} \mathrm{s}^{* * * *}$ & $0.020 \pm 0.003^{\mathrm{a}}$ & $0.010 \pm 0.001^{\mathrm{a}}$ \\
\hline
\end{tabular}

$* \mathrm{p}>0.05$

** $\mathrm{p}<0.05$.

$* * * \mathrm{p}<0.005$.

\subsection{Methods}

\subsubsection{Preparation of chia protein isolates}

Chia protein isolates (CPI) were obtained through isoelectric precipitation. Two different conditions were assayed with the aim of studying the effect of extraction $\mathrm{pH}$ on the surface properties [5]. Milled and partially defatted chia seeds were hydrated with distilled water $(1: 20)$ and stirred for $30 \mathrm{~min}$. After centrifugation for $15 \mathrm{~min}$ at $10,000 \mathrm{~g}$, the intermediate mucilaginous phase was removed. The upper and bottom phases were mixed, and the $\mathrm{pH}$ of this slurry was adjusted to $\mathrm{pH} 10$ or 12 with $\mathrm{NaOH} 1 \mathrm{~mol} / \mathrm{L}$ under stirring for $1 \mathrm{~h}$. Proteins were recovered in the supernatant after centrifugation for $15 \mathrm{~min}$ at $10,000 \mathrm{~g}$ and they were precipitated at $\mathrm{pH} 4.5$ with $\mathrm{HCl} 1 \mathrm{~mol} / \mathrm{L}$. This slurry was kept stirring for $1 \mathrm{~h}$ and then centrifuged for $15 \mathrm{~min}$ at $10,000 \mathrm{~g}$ in order to recover the precipitated proteins. Proteins were dispersed in distilled water at pH 10 or 12 with $\mathrm{NaOH} 1 \mathrm{~mol} / \mathrm{L}$. Samples were freeze-dried and are referred to as CPI10 or CPI12, according to their extraction $\mathrm{pH}$ (10 or 12 , respectively).

\subsubsection{Protein solubility}

The contents of crude protein in both isolates had already been determined by the Kjeldahl procedure and were 78.2 and $77.5 \%$ for CPI10 and CPI12, respectively [5].

Protein solubility was determined in the $\mathrm{pH}$ range of 2-10. The dispersions of both isolates were prepared at $10 \mathrm{~g} / \mathrm{L}$ in distilled water and the $\mathrm{pH}$ was adjusted with $\mathrm{NaOH}$ or $\mathrm{HCl} 1 \mathrm{~mol} / \mathrm{L}$. Samples were stirred for $1 \mathrm{~h}$ and then centrifuged for $15 \mathrm{~min}$ at $10,000 \mathrm{~g}$. The concentration of soluble protein in the supernatant was determined by the bicinchoninic acid assay method [9]. Protein solubility was expressed as a percentage of the total protein. The same procedure was carried out to evaluate the protein solubility in buffer phosphate $0.01 \mathrm{~mol} / \mathrm{L}$ at $\mathrm{pH} 7$ with ionic strength (I) fixed at $0.022 \mathrm{~mol} / \mathrm{L}$ with $\mathrm{NaCl}$.

\subsubsection{Sample preparation}

CPI10 and CPI12 were dispersed in buffer phosphate $0.01 \mathrm{~mol} / \mathrm{L}$ $(\mathrm{I}=0.022 \mathrm{~mol} / \mathrm{L})$ at $\mathrm{pH} 7$ and kept stirring for $1 \mathrm{~h}$. Then, samples were centrifuged at $10,000 \mathrm{~g}$ for $15 \mathrm{~min}$ so as to obtain a final concentration of $1 \mathrm{~g} / \mathrm{L}$ of soluble protein. This concentration enabled a proper study of the kinetics of formation and destabilization of foams and emulsions in the period of time analyzed.

\subsubsection{Interfacial and rheological properties of the air/water interface}

The adsorption of chia proteins to the interfaces and their subsequent rearrangement were determined using a dynamic drop tensiometer (Tracker, IT-Concept, Saint-Clementtes Places, France). Three milliliters of the protein suspensions prepared according to Section 2.2.3. were located in the bucket of the tensiometer and a $3 \mu \mathrm{L}$ bubble of air was formed from the tensiometer syringe. Surface tension $(\mathrm{\gamma})$ data as a function of time were adjusted with a biphasic first order equation [10]:

$\mathrm{y}(\mathrm{t})=\mathrm{\gamma}_{\mathrm{a}} \mathrm{e}^{-\mathrm{kat}}+\mathrm{\gamma}_{\mathrm{r}} \mathrm{e}^{-\mathrm{krt}}+\mathrm{\gamma}_{\mathrm{e}}$

where $\mathrm{k}_{\mathrm{a}}$ and $\mathrm{k}_{\mathrm{r}}$ are the first order rate constants of the adsorption and rearrangement processes, and $\mathrm{\gamma}_{\mathrm{a}}$ and $\mathrm{\gamma}_{\mathrm{r}}$ are their amplitudes, respectively. $\mathrm{\gamma}_{\mathrm{e}}$ is the surface tension at equilibrium.

The interfacial tension was measured for $120 \mathrm{~min}$, until equilibrium was reached. At this moment, the surface dilational modulus (E) and its elastic and viscous components $\left(E_{d}\right.$ and $E_{v}$, respectively) were determined. The amplitude and angular frequency were fixed at $10 \%$ and $200 \mathrm{~Hz}$, respectively. Temperature was fixed throughout the experiment at $20^{\circ} \mathrm{C}$. 

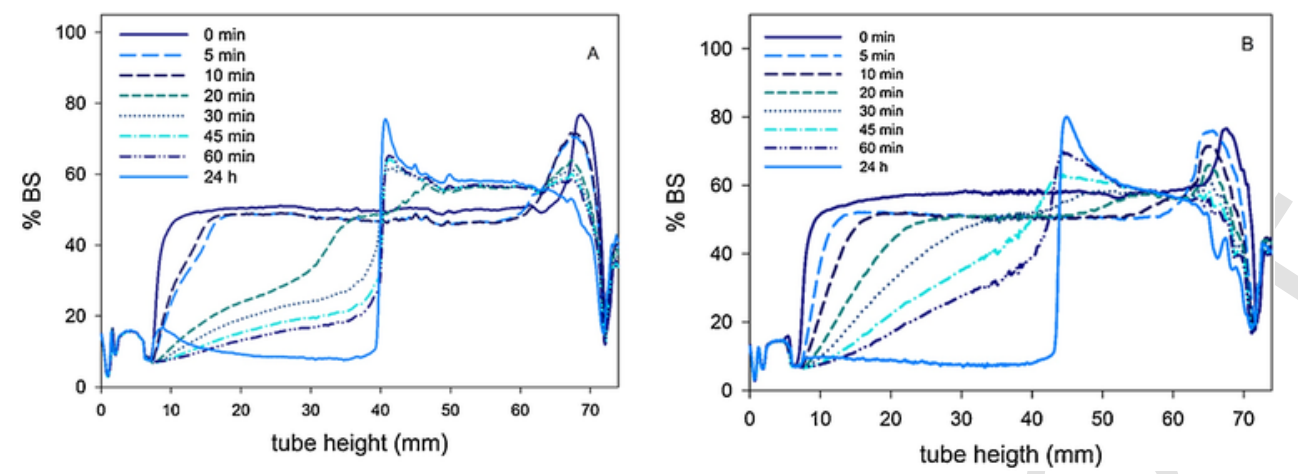

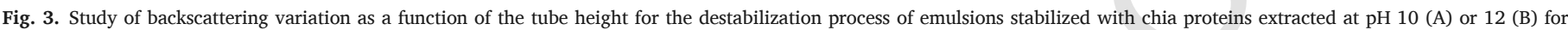
$60 \mathrm{~min}$ and after $24 \mathrm{~h}$ of storage.

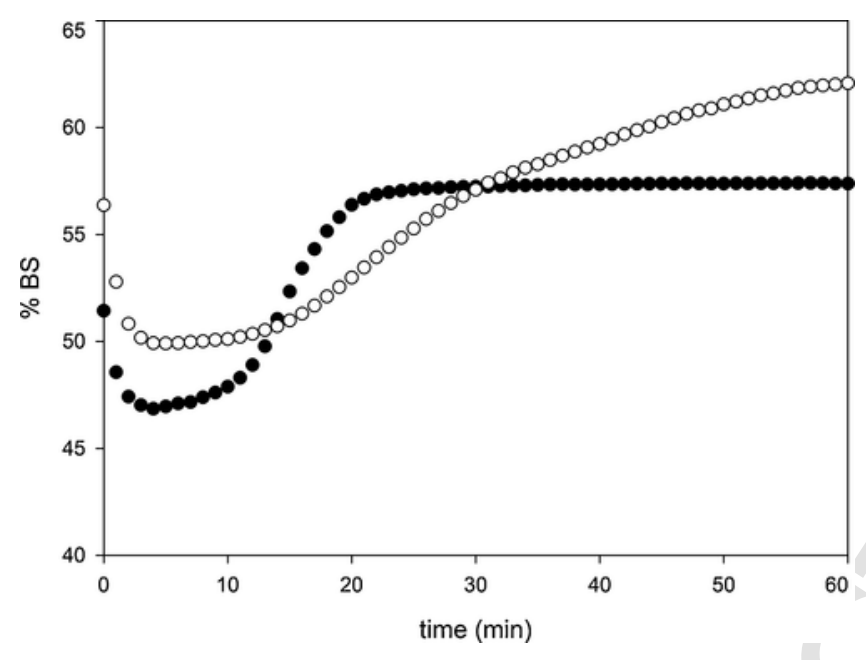

Fig. 4. Backscattering variation in the middle zone of the cream phase for the destabilization process of emulsions stabilized with chia proteins extracted at $\mathrm{pH} 10$ (black circles) and 12 (white circles).

\subsubsection{Study of chia proteins at the air-water interface}

2.2.5.1. Foam formation and destabilization The foaming properties of chia proteins were determined by conductimetry [4,11]. Briefly, foams were formed by means of air bubbling through a G2 type sintered glass disk in a column containing $10 \mathrm{~mL}$ of the protein solution prepared according to Section 2.2.3 until a volume of $60 \mathrm{~mL}$ of foam was formed. The flow rate was fixed at $100 \mathrm{~mL} / \mathrm{min}$.

Conductimetry values, measured as a function of time, were used to calculate the volume of liquid incorporated into the foam. As it has been previously described by Warner et al., this methodology allows the study of the formation of foams by means of the analysis of the volume of liquid incorporated into the foam vs time plot [12]. The initial rate of the liquid incorporated into the foam $\left(\mathrm{v}_{0}\right)$ was determined in order to evaluate the foaming capacity of both CPI.

The kinetics of foam destabilization was also studied based on the application of a second order model [10]:

$\mathrm{V}(\mathrm{t})=\mathrm{V}_{\mathrm{g}}^{2} \mathrm{k}_{\mathrm{g}} \mathrm{t} /\left(\mathrm{V}_{\mathrm{g}}^{2} \mathrm{k}_{\mathrm{g}} \mathrm{t}+1\right)+\mathrm{V}_{\mathrm{d}}^{2} \mathrm{k}_{\mathrm{d}} \mathrm{t} /\left(\mathrm{V}_{\mathrm{d}}^{2} \mathrm{k}_{\mathrm{d}} \mathrm{t}+1\right)$

where $\mathrm{k}_{\mathrm{g}}$ and $\mathrm{V}_{\mathrm{g}}$ are the rate constant and the maximum volume of liquid drained in the foam associated with gravitational drainage, respectively. $k_{d}$ and $V_{d}$ are the rate constant and the maximum volume of liquid drained in the foam associated with gas diffusion or disproportionation processes, respectively.

According to Eq. (2), it is reasonable to consider the destabilization process due to the contribution of two different processes for liquid drainage; one because of drainage itself and the other one due to Ostwald's ripening.

\subsubsection{Study of chia proteins at the oil-water interface}

2.2.6.1. Emulsion preparation Coarse emulsions were prepared by mixing $5 \mathrm{~mL}$ of a commercial oil with $15 \mathrm{~mL}$ of a protein dispersion -prepared according to Section 2.2.4.- with a high-speed homogenizer (Ultra-Turrax T25 Ika Labortechnik, GmbH \& Co., Staufen, Germany) at $20,000 \mathrm{rpm}$ for $1 \mathrm{~min}$. The commercial oil used was a mixture of $5 \%$ of corn and $95 \%$ of sunflower oils.

2.2.6.2. Droplet size distribution The particle size distribution of freshly made emulsions was determined by laser diffraction using a particle size analyzer (Coulter Counter Multisizer, Coulter Electronics Ltd., High Wycombe, UK). The De Brouckere mean diameters $\left(D_{4,3}\right)$ were calculated with and without treatment with buffer Tris/ $\mathrm{HCl} 50 \mathrm{mmol} /$ $\mathrm{L}, \mathrm{pH} 8,10 \mathrm{~g} / \mathrm{L}$ SDS, in a 1:1 proportion in order to measure a mean droplet size avoiding flocculation.

2.2.6.3. Kinetics of emulsion destabilization Global emulsion stability was determined with a vertical optical analyzer (Turbiscan Classic MA 2000, Formulaction, Toulouse, France). The backscattering (BS) profiles for both emulsions were measured every $1 \mathrm{~min}$ for $60 \mathrm{~min}$. The reduction of backscattering values in the lower zone of the tube $(10-15 \mathrm{~mm})$ as a function of time was analyzed according to Panizzolo et al. [13]:

$\mathrm{BS}(\mathrm{t})=\mathrm{BS}_{\mathrm{h}} /\left(\mathrm{BS}_{\mathrm{h}} \mathrm{k}_{\mathrm{h}} \mathrm{t}+1\right)+\mathrm{BS}_{\mathrm{s}} /\left(\mathrm{BS}_{\mathrm{s}} \mathrm{k}_{\mathrm{s}} \mathrm{t}+1\right)$

where $\mathrm{k}_{\mathrm{h}}$ and $\mathrm{k}_{\mathrm{s}}$ are the $\mathrm{BS}$ variation rates for a second order kinetics and a sigmoidal kinetic model, respectively. $\mathrm{BS}_{\mathrm{h}}$ and $\mathrm{BS}_{\mathrm{s}}$ are the amplitude parameters of the aforementioned kinetics models.

$\mathrm{BS}_{\mathrm{h}}$ and $\mathrm{BS}_{\mathrm{s}}$ determine the extent to which each one contribute to the overall destabilization process, and therefore it is more appropriate to inform the ratio $\mathrm{BS}_{\mathrm{h}} / \mathrm{BS}_{\mathrm{s}}$ [14].

The backscattering profiles were also analyzed $24 \mathrm{~h}$ after emulsion formation in order to evaluate the overall destabilization. The overall degree of destabilization (\%D) was calculated using the maximum mean values of BS in the $50-53 \mathrm{~mm}$ zone (Eq. (4)):

$\% \mathrm{D}=\left(\mathrm{BS}_{\max }-\mathrm{BS}_{24 \mathrm{~h}}\right) / \mathrm{BS}_{\max } * 100$

where $\mathrm{BS}_{\max }$ is the mean of the maximum backscattering values in the period of time from 0 to $60 \mathrm{~min}$, and $\mathrm{BS}_{24 \mathrm{~h}}$ is the mean of backscattering values after $24 \mathrm{~h}$ of storage [15].

\subsubsection{Statistical analysis}

All the experiments were carried out at least in triplicate. Significant differences among mean values $(\alpha=0.05)$ were determined by means of t-tests. 


\section{Results and discussion}

\subsection{Protein solubility}

Solubility, which is considered to be one of the most important properties affecting the whole protein functionality, is significantly influenced by the protein denaturation state [16]. In fact, proteins with low solubility exhibit limited functional properties and therefore, limited use in the food industry.

Fig. 1 shows the solubility profiles obtained for CPI10 and CPI12.

The lowest protein solubility was reached at $\mathrm{pH} 2$ for both isolation conditions, and it was significantly lower for CPI12. The protein solubility showed high values, without significant differences in the $\mathrm{pH}$ range from 3 to 12. Therefore, both profiles obtained showed differences from those previously reported by other authors, which exhibited clear U-shaped curves [2]. In the present work, both CPI showed higher contents of soluble protein in the $\mathrm{pH}$ range $3-10$, above $45 \mathrm{mg}$ soluble protein/100 mg crude protein, when compared to previous reports [2].

Protein solubility was lower for CPI12 than for CPI10 throughout the $\mathrm{pH}$ range analyzed. This fact is closely related to the higher content of unordered structures as well as the higher extent of protein aggregation observed for proteins extracted at $\mathrm{pH} 12$, as reported in a previous study. Besides, as it has been previously reported, the enthalpy of denaturation of CPI10 is higher than that of CPI12 [5]. These results suggest that unfolding of the protein due to extreme alkali treatment leads to a decrease in solubility. The increased protein denaturation is in accordance with the higher extent of protein aggregation, which led to the formation of insoluble particles.

The percentage of soluble protein in buffer phosphate $0.01 \mathrm{~mol} / \mathrm{L}$ $(\mathrm{pH} 7, \mathrm{I}=0.022 \mathrm{~mol} / \mathrm{L})$ was also calculated as described in Section 2.2.2 for both protein isolates. CPI10 showed a significantly higher protein solubility than CPI12 (87 $\pm 2 \%$ for CPI10 and $33 \pm 2 \%$ for CPI12).

\subsection{Foaming properties of chia proteins}

\subsubsection{Interfacial rheology of the air/water interface}

The adsorption and rearrangement of chia proteins at the air/water interface were studied (Fig. 2).

At first, the reduction of interfacial tension over time shown in Fig. 2 was marked in both samples studied. Therefore, protein diffusion did not restrict the adsorption process. Later, a second step took place, at which the reduction in the interfacial tension was slower until a constant value was reached, which marked the attainment of equilibrium.

The first order rate constants of the adsorption $\left(\mathrm{k}_{\mathrm{a}}\right)$ and rearrangement $\left(\mathrm{k}_{\mathrm{r}}\right)$ processes were estimated and are shown in Table 1 .

The obtained $\mathrm{k}_{\mathrm{a}}$ did not show significant differences between both samples studied $(\mathrm{p}=0.0954)$. Therefore, the extraction $\mathrm{pH}$ did not influence the rate at which chia proteins are adsorbed to the air/water interface. The analysis of $\gamma_{a}$, used to estimate the reduction of the surface free energy caused by the adsorbed proteins [4] showed therefore no significant differences between both samples $(\mathrm{p}=0.1736)$.

A different protein rearrangement rate at the interface was described by the differences observed in the $\mathrm{k}_{\mathrm{r}}$ values $(\mathrm{p}=0.0038)$. Consistent with this, the amplitude of the decrease in surface tension due to rearrangement $\left(\mathrm{\gamma}_{\mathrm{r}}\right)$ was significantly higher for CPI10 $(\mathrm{p}=0.0117)$.

The fact that $\mathrm{k}_{\mathrm{a}}$ was at least an order of magnitude higher than $\mathrm{k}_{\mathrm{r}}$ means that the adsorption process takes place faster than the protein rearrangement at the interface in both samples.

The ability of chia proteins to form a stable film at the air/water interface was analyzed by means of interfacial rheology (Table 1). The significantly higher $\mathrm{E}$ value obtained for the air/water interface stabilized by CPI10 ( $\mathrm{p}<0.0001)$ suggests a high intra-protein flexibility as well as an enhanced protein network strength [17]. A stable film requires not only an elastic surface to absorb external shocks, but also an increased surface viscosity to decrease mechanical distortions [18]. Both moduli, $E_{v}$ and $E_{d}$, were higher for CPI10 ( $\left.p<0.0001\right)$, explaining the formation of a stronger film with greater stability.

\subsubsection{Kinetics of foam formation and destabilization}

CPI were evaluated against their properties of foam formation and destabilization at neutral $\mathrm{pH}$. The results obtained are shown in Table 1.

The initial rate of the liquid incorporated into the foam $\left(\mathrm{v}_{0}\right)$ was higher for CPI10 than for CPI12 ( $p=0.0055)$. It should be noted that the destabilization processes occur simultaneously with the formation of the foam. Therefore, the higher $\mathrm{v}_{0}$ obtained for foams formed by CPI10 may be associated with a greater resistance to the destabilization processes [19].

During foam destabilization, different mechanisms of liquid drainage, either due to gravity or to disproportion, are involved. Rate constants for both the gravity drainage process $\left(\mathrm{k}_{\mathrm{g}}\right)$ and the disproportion process $\left(\mathrm{k}_{\mathrm{d}}\right)$ have been estimated and are shown in Table 1 .

The fact that $\mathrm{k}_{\mathrm{g}}$ was at least one order of magnitude higher than $\mathrm{k}_{\mathrm{d}}$ suggests that gravity drainage occurs faster than drainage due to disproportion. Both samples showed similar $\mathrm{k}_{\mathrm{g}}$, without significant differences between them $(p=0.8837)$; whereas a higher $k_{d}$ was obtained for foams stabilized with CPI12 ( $\mathrm{p}=0.0015)$.

Foams formed by CPI10 showed a higher volume of liquid drainage due to gravity $\left(\mathrm{V}_{\mathrm{g}}\right)(\mathrm{p}=0.0069)$ while a lower volume of liquid drainage due to Ostwald disproportion $\left(\mathrm{V}_{\mathrm{d}}\right)(\mathrm{p}=0.0085)$. It is important to highlight that $\mathrm{V}_{\mathrm{g}}$ and $\mathrm{V}_{\mathrm{d}}$, unlike $\mathrm{k}_{\mathrm{g}}$ and $\mathrm{k}_{\mathrm{d}}$, depend on each other.

The lower extent of Ostwald ripening present in foams formed by CPI10 is related to the higher $\mathrm{E}_{\mathrm{d}}$ value obtained [11]. Disproportion was therefore inhibited due to the formation of a thick layer, which prevents the passage of gas.

As it has been previously reported, the extraction procedure induces conformational changes in chia proteins. The surface hydrophobicity has been reported in a previous work and was higher for CPI10 than for CPI12. Although the denaturation degree was determined to be higher in CPI12, the association among proteins through hydrophobic interactions led to large aggregates of proteins which exposed lower hydrophobic patches [6].

It is to be noted that the exposure of more hydrophobic residues due to unfolding in CPI10 led to small proteins with a greater flexibility, which enabled increased interactions at the air/water interface. Because of this, these proteins exhibited greater surface activity with improved foaming properties [12].

\subsection{Emulsifying properties of chia proteins}

\subsubsection{Droplet size distribution}

The particle size distribution of both samples studied was bimodal as a consequence of the homogenization process. Mean values of De Brouckere diameters $\left(D_{4,3}\right)$ were $35.7 \pm 0.7 \mu \mathrm{m}$ and $32.2 \pm 0.2 \mu \mathrm{m}$ for emulsions stabilized with CPI10 and CPI12, respectively, with significant differences between both samples $(\mathrm{p}=0.0223)$. This polydispersion was also observed in the presence of SDS. The $\mathrm{D}_{4,3}$ diameters obtained did not show significant differences in the absence and the presence of SDS ( $p=0.1829)$, suggesting a lack of aggregates formed by non-covalent interactions. Thus, emulsions stabilized by CPI10 were formed by droplets with a higher mean size than those formed by CPI12. 


\subsubsection{Emulsion destabilization kinetics}

The BS profiles were analyzed for $60 \mathrm{~min}$ and after $24 \mathrm{~h}$ of storage in order to evaluate the creaming-flocculation kinetics of the emulsions. The results are shown in Fig. 3.

The reduction in the BS in the lower zone of the tube accounts for the movement of oil droplets to the upper zone, which is related to the development of the creaming process. The analysis of the BS variation vs time profiles in the lower zone of the tube $(10-15 \mathrm{~mm})$ showed sigmoidal curves in both samples, which were evaluated with a two-term kinetic model, according to Eq. (4). As it has been described by Panizzolo et al., this sigmoidal profile is consistent with the presence of two populations with different droplet sizes, as previously discussed in Section 3.3.1. Large droplets with the highest creaming rate are expected to migrate faster to the upper zone of the tube. The deviation from Stoke's law in emulsions with sigmoidal profiles reflects that the movement of large droplets is delayed in the first time interval by the small droplets. Then, this effect decreases its extent and incidence and the creaming process behaves like emulsions with a hyperbolic backscattering profile [13].

The $k_{h}$ value is related to the creaming of small particles whereas the value of $\mathrm{k}_{\mathrm{s}}$ is linked to the creaming of the large particles. Emulsions stabilized with CPI10 showed a higher $\mathrm{k}_{\mathrm{h}}$ value, which could be ascribed to a higher rate of destabilization.

The results obtained showed a significantly lower $\mathrm{BS}_{\mathrm{h}} / \mathrm{BS}_{\mathrm{s}}$ ratio for emulsions stabilized by CPI12 $(\mathrm{p}=0.0046)$, due to the significantly higher contribution of the sigmoidal behavior to the BS [20].

The analysis of the mean values of BS in the middle zone of the cream phase allowed us to follow the flocculation and/or coalescence processes in the cream phase. Both emulsions showed a similar BS vs time profile (Fig. 4).

Initially, a reduction in BS was observed, followed by an increase, until a certain time at which a constant value was reached. This behavior is in accordance with the variation in the number and size of the droplets present in the cream phase. Indeed, the time at which each emulsion reached the maximum BS value is related to the balance between the rates of accumulation and diminution in the number of droplets. The BS maximum mean value was reached at about $20 \mathrm{~min}$ for CPI10, after which a wide peak was observed in Fig. 3, which is related to the accumulation of small droplets with low creaming rate [15]. As regards emulsions stabilized with CPI12, the BS maximum value was reached significantly later (near $60 \mathrm{~min}$ ), which is related to the higher global stability of emulsions stabilized with CPI12 due to the formation of a stable cream phase at a slower rate.

Coalescence is considered to be a slow destabilization process for emulsions prepared with low concentrations of proteins when used as the only emulsifying agent, as compared to creaming and flocculation processes [21]. Therefore, emulsions were stored under quiescent conditions at $20^{\circ} \mathrm{C}$ in order to detect coalescence. Emulsions stabilized with chia proteins exhibited similar BS values in the middle zone of the cream phase when compared to those obtained for freshly made emulsions. This fact suggests the lack of a significant droplet size increase after $24 \mathrm{~h}$ of incubation. After $24 \mathrm{~h}$ storage, clarification may be observed as the BS is close to zero in both samples [22].

The overall degree of destabilization (\%D) was calculated according to Eq. (4) in order to estimate the global destabilization of the cream phase, from its formation to the end of storage. As this index reflects the decrease in BS associated with a diminution in the number of droplets, it may be associated with flocculation or coalescence. Emulsions stabilized with CPI12 showed a significantly lower $\% \mathrm{D}(\% \mathrm{D}=0.014 \pm 0.003)$ than those stabilized with CPI10 $(\% \mathrm{D}=1.8 \pm 0.3)$. The fact that $\mathrm{BS}$ in the cream zone did not vary significantly from $60 \mathrm{~min}$ to $24 \mathrm{~h}$ of storage showed that these samples did not experience further droplet size increase.
As it has been previously concluded by Ajibola et al., adequate emulsifying abilities do not necessarily correlate with good foaming properties, suggesting that different mechanisms underlie the formation of foam and emulsions [23].

\section{Conclusions}

Chia proteins extracted at $\mathrm{pH} 10$ showed better foaming properties than those extracted at $\mathrm{pH} 12$. The formation of a thick interfacial film ensured a greater ability of these foams to retard drainage due to disproportion. In connection with this, the higher rate of liquid incorporation into the foam observed for CPI10 is due to the ability to retard destabilization processes. The formation as well as the stabilization of such colloidal systems were favored by the presence of flexible soluble proteins which exposed higher surface hydrophobicity, leading to intermolecular interaction within the interfacial film. As regards the emulsification properties of chia proteins, the concentration of soluble protein studied allowed us to analyze the kinetics of destabilization. Both samples showed sigmoidal destabilization profiles, related to the existence of two populations with different droplet sizes. The sigmoidal component contribution was significantly higher for emulsions stabilized with CPI12. The differences in the kinetics of destabilization is caused by the creaming process of the small droplets. The delaying effect of the small droplets to the creaming process of larger droplets is more evident in the aforementioned sample, leading to a slower formation of a stable cream phase. Besides, a slight degree of coalescence after $24 \mathrm{~h}$ of storage was observed for emulsions stabilized with CPI12.

The extraction of chia proteins at different pHs affects their structural characteristics which profoundly influence their interfacial properties.

\section{Acknowledgments}

This work was supported by grants from Agencia Nacional de Promoción Científica y Tecnológica (PICT 2017-0937), Universidad Católica Argentina and from Universidad Nacional de Rosario (1BIO585). The authors would like to thank the English Department of Facultad de Ciencias Bioquímicas y Farmacéuticas, UNR, for manuscript revision. Débora N. López would also like to thank Consejo Nacional de Investigaciones Científicas y Técnicas (CONICET) and Red Iberoamericana CYTED 415RT0495 for the fellowships she was granted.

\section{References}

[1] O.L. Tavano, S.I. da Silva, A. Demonte, V.A. Neves, Nutritional responses of rats to diets based on chickpea (Cicer arietinum L.) seed meal or its protein fractions, J. Agric. Food Chem. 56 (2008) 11006-11010.

[2] Y.P. Timilsena, R. Adhikari, C.J. Barrow, B. Adhikari, Physicochemical and functional properties of protein isolate produced from Australian chia seeds, Food Chem. 212 (2016) 648-656.

[3] M. Silveira Coelho, M. de las Mercedes Salas-Mellado, Chemical characterization of Chia (Salvia hispanica L.) for use in food products, J. Food Nutr. Res. 2 (2014) 263-269.

[4] A.J. Bolontrade, A.A. Scilingo, M.C. Añón, Amaranth proteins foaming properties: adsorption kinetics and foam formation - part 1, Colloids Surf. B Biointerfaces 105 (2013) 319-327.

[5] D.N. López, R. Ingrassia, P. Busti, J. Bonino, J.F. Delgado, J. Wagner, V. Boeris, D. Spelzini, Structural characterization of protein isolates obtained from chia (Salvia hispanica L.) seeds, LWT Food Sci. Technol. 90 (2018) 396-402.

[6] D.N. López, R. Ingrassia, P. Busti, J. Wagner, V. Boeris, D. Spelzini, Effects of extraction $\mathrm{pH}$ of chia protein isolates on functional properties, LWT Food Sci. Technol. 97 (2018) 523-529, https://doi.org/10.1016/J.LWT.2018.07.036.

[7] A. Vázquez-Ovando, D. Betancur-Ancona, L. Chel-Guerrero, Physicochemical and functional properties of a protein-rich fraction produced by dry fractionation of chia seeds (Salvia hispanica L.), CYTA J. Food. 11 (2013) 75-80.

[8] B.L. Olivos-Lugo, M.Á. Valdivia-López, A. Tecante, Thermal and physicochemical properties and nutritional value of the protein fraction of mexican chia seed (Salvia hispanica L.), Food Sci. Technol. Int. 16 (2010) 89-96.

[9] P.K. Smith, R.I. Krohn, G.T. Hermanson, A.K. Mallia, F.H. Gartner, M.D. Provenzano, E.K. Fujimoto, N.M. Goeke, B.J. Olson, D.C. Klenk, Measurement of protein using bicinchoninic acid, Anal. Biochem. 150 (1985) 76-85. 
[10] L.A. Panizzolo, L.E. Mussio, M.C. Añón, A kinetic description for the destabilization process of protein foams, Int. J. Food Prop. 15 (2012) 60-68.

[11] C. Abirached, C.A. Medrano, A.C. Araujo, P. Moyna, M.C. Añón, L.A. Panizzolo, Comparison of interfacial and foaming properties of soy and whey protein isolates, J. Food Sci. Eng. 2 (2012) 376-381.

[12] J.R. Wagner, D.A. Sorgentini, M.C. Añón, Thermal and electrophoretic behavior, hydrophobicity, and some functional properties of acid-treated soy isolates, J. Agric. Food Chem. 44 (1996) 1881-1889.

[13] L.A. Panizzolo, L.E. Mussio, M.C. Añón, Kinetics for describing the creaming of protein-stabilized O/W emulsions by multiple light scattering, J. Food Sci. Eng. 4 (2014) 236-243.

[14] L.A. Panizzolo, L.E. Mussio, A kinetic model for describing the effect of proteins on the air-water interface tension, J. Food Sci. Eng. 4 (2014) 282-290.

[15] G.G. Palazolo, D.A. Sorgentini, J.R. Wagner, Coalescence and flocculation in o/w emulsions of native and denatured whey soy proteins in comparison with soy protein isolates, Food Hydrocoll. 19 (2005) 595-604.

[16] J.E. Kinsella, Functional properties of soy proteins, J. Am. Oil Chem. 56 (1979) 242-258.
[17] S. Damodaran, Protein stabilization of emulsions and foams, J. Food Sci. 70 (2006) 54-66.

[18] C. Stubenrauch, R. Miller, Stability of foam films and surface rheology: an oscillating bubble study at low frequencies, J. Phys. Chem. B108 (2004) 6412-6421.

[19] L.A. Panizzolo, M.C. Añón, Foaming properties of soy protein isolate hydrolysates, J. Food Nutr. Sci. 3 (2015) 1-9.

[20] L.A. Panizzolo, M.C. Añón, Emulsifying properties of hydrolysates isolated from soybean protein, Int. J. Nutr. Food Sci. 4 (2015) 223-233.

[21] M. Britten, H.J. Giroux, Coalescence index of protein-stabilized emulsions, J. Food Sci. 56 (1991) 792-795.

[22] G.G. Palazolo, D.A. Sorgentini, J.R. Wagner, Emulsifying properties and surface behavior of native and denatured whey soy proteins in comparison with other proteins. Creaming stability of oil-in-water emulsions, J. Am. Oil Chem. Soc. 81 (2004) 625-632.

[23] C.F. Ajibola, S.A. Malomo, T.N. Fagbemi, R.E. Aluko, Polypeptide composition and functional properties of African yam bean seed (Sphenostylis stenocarpa) albumin, globulin and protein concentrate, Food Hydrocoll. 56 (2016) 189-200. 